Research Article

\title{
Quantification of Hydrogen Peroxide in Cretan Honey and Correlation with Physicochemical Parameters
}

\author{
Amalia Alygizou, ${ }^{1}$ Spyros Grigorakis, ${ }^{1}$ Panagiota Gotsiou, ${ }^{1}$ Sofia Loupassaki, ${ }^{1}$ \\ and Antony C. Calokerinos $\mathbb{B}^{2}$ \\ ${ }^{1}$ Department of Food Quality \& Chemistry of Natural Products, Mediterranean Agronomic Institute of Chania (M.A.I.Ch.), \\ Centre International de Hautes Etudes Agronomiques Méditerranéennes, P.O. Box 85, Chania 73100, Greece \\ ${ }^{2}$ Department of Chemistry, School of Physical Science, National and Kapodistrian University of Athens, Panepistimiopolis, \\ Athens 15771, Greece
}

Correspondence should be addressed to Antony C. Calokerinos; calokerinos@chem.uoa.gr

Received 11 February 2021; Revised 17 March 2021; Accepted 21 April 2021; Published 27 April 2021

Academic Editor: María José Trujillo-Rodríguez

Copyright (C) 2021 Amalia Alygizou et al. This is an open access article distributed under the Creative Commons Attribution License, which permits unrestricted use, distribution, and reproduction in any medium, provided the original work is properly cited.

\begin{abstract}
The aim of the present study is to quantify hydrogen peroxide, generated from various types of honey produced in Crete, as a potent antimicrobial agent, and establish any correlation with their physicochemical parameters. The basic physicochemical parameters (diastase activity, HMF content, moisture, electrical conductivity, color, and sugars) of 30 authentic honey samples were determined. The concentration of hydrogen peroxide in all samples was found to be within the range $0.010-0.092 \mathrm{mM}$. The known correlation between the electrical conductivity and the color of honey was confirmed in this study. Univariate and multivariate statistics applied to the results indicate that the results can be used to discriminate honey sample groups of different botanical origins.
\end{abstract}

\section{Introduction}

Honey besides its antioxidant, anti-inflammatory, and antimutagenic effects is also widely known for its antibacterial properties. It has been recorded as a medicine from ancient times due to wound-healing properties. There are several mechanisms responsible for the antibacterial properties of honey. Hydrogen peroxide is produced by the Apis mellifera (honeybee) glucose oxidase (GO) enzyme during dilution of honey, and it is produced in low but effective concentrations. Due to the slow release of hydrogen peroxide, there is much less cytotoxic damage to the cells of the patient, providing a more effective method than applying hydrogen peroxide directly to wounds [1].

Glucose oxidase (GOX) is most active in diluted or unripe honey, and when the sugar concentration is within $25-30 \%(\mathrm{w} / \mathrm{w})$, hydrogen peroxide is produced:

$$
\beta-\mathrm{D}-\text { Glucose }+\mathrm{H}_{2} \mathrm{O}+\mathrm{O}_{2}+\mathrm{GO} \longrightarrow \text { gluconic acid }+\mathrm{H}_{2} \mathrm{O}_{2}
$$

Prolonged storage of honey reduces peroxide accumulation due to reduction of enzyme activity [2].

The evaluation of the endogenous hydrogen peroxide levels in honey can be of great value to predict the hydrogen peroxide-dependent antibacterial activity of honey and also to characterize or select honey samples for their use as an antibacterial agent or natural food preservative. 
Environmental conditions can affect the physiology of the floral species or bee-related characteristics such as age or colony health, which might further affect the production of glucose oxidase [3].

Furthermore, accumulation of hydrogen peroxide of honey is affected by the content of glucose oxidase which appears to be formed during ripening. It is also affected by various minor components (nectar, pollen, and yeasts). The peroxide accumulation value of the honey also depends on the presence of high vitamin $\mathrm{C}$ content, handling, storage, and processing of honey. Moreover, pollen-derived catalase effectively hydrolyzes hydrogen peroxide to oxygen and water and is considered as a potent blocker of hydrogen peroxide accumulation [4-6].

Other studies have shown that the diversity in floral resources can have a direct effect on immune and bacterial factors and therefore on the glucose oxidase. Therefore, the level of hydrogen peroxide is the outcome of a dynamic equilibrium between the rate of its production and the rate of its destruction $[7,8]$.

The rate of hydrogen peroxide production also depends on dilution of honey. Bang et al. [9] reported that the maximum accumulation of hydrogen peroxide was achieved at $30 \%-50 \%(\mathrm{v} / \mathrm{v})$ aqueous honey solutions. This can be explained by a factor that a certain degree of honey dilution facilitates access of the GOX to its substrate (glucose) and prevents GOX inhibition due to milieu acidification [10]. Moreover, apart from the glucoseglucose oxidase system, the auto-oxidation of polyphenols and flavonoids could degrade or destroy hydrogen peroxide. As reported by Brudzynski et al. [11] at low content, polyphenols in honey interact with hydrogen peroxide in the metal-catalyzed Fenton reaction to confer the oxidation action of hydrogen peroxide via generation of the hydroxyl radical, which is responsible for the oxidative damage to DNA caused by honey rather than molecular hydrogen peroxide [12].

All the above factors can, therefore, affect the hydrogen peroxide concentration of honey. Possibly nectar-derived peroxidases rather than catalase might be a cause of variation in the hydrogen peroxide-neutralizing capacity of different honey [1], and this has to be further studied in Cretan honey with relatively lower hydrogen peroxide production.

Since Crete is a major producer of honey in Greece but the most common quality characteristics have not been studied in detail, it was decided (a) to determine diastase activity, HMF content, moisture, electrical conductivity, color, and sugars in four different botanical groups (thyme honey, PDO "Pefkothymaromelo Kritis" honey (blend thyme-pine honey), pine honey, and Citrus honey), (b) to determine the amount of hydrogen peroxide produced after $30 \%(\mathrm{w} / \mathrm{v})$ dilution with water, and (c) to establish any correlation between results. Although hydrogen peroxide in honey can be determined by using techniques like spectrophotometry, spectrofluorimetry, electrochemistry, chromatography, and chemiluminescence [13-17], in this work, it was decided to apply a hydrogen peroxide/peroxidase assay. To our knowledge, this is the first time that hydrogen peroxide in honey samples from Crete is quantified.

\section{Materials and Methods}

2.1. Materials and Chemicals. The following chemicals were supplied from Sigma-Aldrich Co. (St. Louis, MO, USA): hydrochloric acid, ammonium hydroxide (28-30\% v/v), ethanol $(95 \% \mathrm{v} / \mathrm{v})$, sodium nitrate $(\geq 98 \% \mathrm{w} / \mathrm{w})$, sulfuric acid $(20 \% \mathrm{v} / \mathrm{v})$, sodium thiosulfate solution $(0.10 \mathrm{~N})$, sodium acetate buffer $\mathrm{pH}$ 5.30, potassium hexacyanoferrate(II) trihydrate, sodium acetate trihydrate $(\geq 98.5 \% \mathrm{w} / \mathrm{w})$, zinc acetate dehydrate $(\geq 98 \% \mathrm{w} / \mathrm{w})$, sodium bisulfate, sodium metabisulfite ( $\geq 97.0 \% \mathrm{w} / \mathrm{w})$, D-(-)-fructose, sucrose, D-(+)glucose, peroxidase from horseradish type II, and o-dianisidine (peroxidase substrate). From Merck (Germany), the following were obtained: potassium iodide for analysis EMSURE $^{\circledR}$ ISO, Reagent Ph Eur, starch (soluble guaranteed reagent for analysis), phosphate buffer $\mathrm{pH}=6.50$, and hydrogen peroxide $(30 \% \mathrm{v} / \mathrm{v})$. Sodium chloride was supplied from Penta (Czech Republic), glycerol standard reference from Hanna Instruments (Gunstock, Rhode Island, USA), and acetonitrile Chromasolv ${ }^{\mathrm{TM}}$, for HPLC, gradient grade ( $\geq 99.9 \%)$ from Honeywell, Riedel-de Haën.

Ultrapure water of HPLC grade from an ultrapure water purification system with resistance of $12-18 \mu \Omega-\mathrm{cm}$ was used throughout.

2.2. Apparatus. An HPLC chromatograph (Agilent 1100) with sample loop $20 \mu \mathrm{l}$ was used with column Lichrospher $100-\mathrm{NH} 2,250 \times 4 \mathrm{~mm}$ i.d., $5 \mu \mathrm{m}$ (Merck 1.50834), precolumn Lichrospher 100-NH2, $5 \mu \mathrm{m}$ (Merck 50958), and refractive index detector (Shodex RI-71, Japan).

All spectrophotometric measurements were made with a UV-visible diode array spectrophotometer (UvLine9400, Schott Instruments, USA).

A Conductivity Pocket Meter (Cond330i WTW, Germany) with cell (TetraCon 325/S, WTW, Germany), an AR 200 Automatic Digital Refractometer (Leica, Germany), and a Honey Color Photometer (HI 96785, Hanna Instruments, USA) were also used.

2.3. Honey Samples. Thirty honey samples of four botanical groups (thyme honey, PDO "Pefkothymaromelo Kritis" honey (blend thyme-pine honey), pine honey, and Citrus honey) were collected from different regions of Crete, coded, and stored at $-20^{\circ} \mathrm{C}$ until analysis.

\subsection{Methods}

2.4.1. Moisture Content. The moisture content $(W)$ of honey was determined by a digital refractometer according to the method by the International Honey Commission [18], and calculations were made by using the following equation:

$$
W=\frac{1.73190-\log (\mathrm{RI})}{0.002243},
$$

where $W$ is the water content in $g$ per $100 \mathrm{~g}$ of honey and RI is the refractive index. 
2.4.2. Electrical Conductivity. $10 \mathrm{~g}$ of dry sample was dissolved in $50.0 \mathrm{~mL}$ of deionized water. After complete mixing, the electrodes of the digital conductivity meter were inserted into the solution and the electrical conductivity $\left(S_{H}\right.$ in $\mathrm{mS} /$ $\mathrm{cm}$ abbreviated as EC) was calculated by the following formula [18]:

$$
S_{H}=K \times G \text {, }
$$

where $K$ is the cell constant $\left(\mathrm{cm}^{-1}\right)$ and $G$ is the conductance $(\mathrm{mS})$.

2.4.3. Hydroxymethylfurfural

Content. Hydroxymethylfurfural content is determined after White according to the Harmonized Methods of the International Honey Commission [18]. More specifically, Carrez I solution ( $15.0 \mathrm{~g}$ of potassium hexacyanoferrate(II) dissolved in deionized water and diluted with deionized water to $100 \mathrm{~mL}$ ) and Carrez II solution (30.0 g of zinc acetate dissolved in deionized water and diluted with deionized water to $100 \mathrm{~mL}$ ) were prepared.

$5.00 \mathrm{~g}$ of honey was mixed with $25 \mathrm{~mL}$ of deionized water and $0.5 \mathrm{~mL}$ Carrez I solution. After mixing the solutions, $0.5 \mathrm{~mL}$ of Carrez II solution was added and the mixture was diluted with deionized water to $50.00 \mathrm{~mL}$. Filter the solution and transfer $5.00 \mathrm{~mL}$ of filtrate into each of two test tubes. Into one test tube transfer $5.00 \mathrm{~mL}$ of deionized water for the analyte measurement and into the other test tube transfer $5.00 \mathrm{ml}$ of $0.20 \% \mathrm{w} / \mathrm{v}$ sodium bisulfite for the reference measurement. Measure the absorbance of the sample against the reference at 284 and $336 \mathrm{~nm}$. The HMF content is calculated by using the following equation:

$$
\begin{aligned}
\operatorname{HMF}(\mathrm{mg} / \mathrm{kg} \text { of honey })= & \left(\mathrm{Abs}_{284}-\mathrm{Abs}_{336}\right) \times 149.7 \\
& \times 5 \times \mathrm{D} / \mathrm{W}
\end{aligned}
$$

where $\mathrm{Abs}_{284}$ and $\mathrm{Abs}_{336}$ are the absorbances at 284 and $336 \mathrm{~nm}$, respectively, 149.7 and 5 are constants, $D$ is the dilution factor if dilution of the sample is necessary, and $W$ is the weight of the honey sample $(\mathrm{g})$.

2.4.4. Diastase Activity. Diastase activity is determined by using the Schade method according to the Harmonized Methods of the International Honey Commission [18].

2.4.5. Honey Color Analysis. The color of the studied honey samples is analyzed with a HANNA Honey Color Photometer. The homogenous honey samples free from air bubbles are transferred into the cuvette $(10 \mathrm{~mm})$ which is introduced into the photometer. Color grades are compared to the glycerol standard and expressed in Pfund grades $(\mathrm{mm})$.

2.4.6. Determination of Hydrogen Peroxide. The concentration of hydrogen peroxide was enzymatically determined as described by White [19] and modified by Kwakman et al. [20]. The method is based on the reaction of hydrogen peroxide with $o$-dianisidine in the presence of horseradish peroxidase type II to form a colored product (brown color). Oxidized $o$-dianisidine reacts with sulfuric acid to form a more stable colored product (pink color). The intensity of the pink color measured at $540 \mathrm{~nm}$ is proportional to the original glucose concentration. For this analysis, 30\% (w/v) water honey solutions were used. More specifically, $10 \mathrm{~g}$ of honey samples was dissolved in $5 \mathrm{~mL}$ of buffer $(0.4 \mathrm{M}$ $\mathrm{pH}=6.50)$ and diluted on water until $25 \mathrm{~mL}$. Then, the honey solutions were filtered through Whatman paper twice after which $120 \mathrm{~mL}$ of honey samples was added to $400 \mathrm{~mL}$ of peroxide reagent consisting of $50 \mu \mathrm{g} / \mathrm{mL} o$-dianisidine and $40 \mu \mathrm{g} / \mathrm{mL}$ of horseradish peroxidase type II. The peroxide reagent was freshly prepared by mixing $5 \mathrm{~mL}$ of phosphate buffer $(0.4 \mathrm{M}, \mathrm{pH}=6.50)$ and $10 \mathrm{mg}$ of $o$-dianisidine diluted to $2 \mathrm{~mL}$ of ethanol and then diluted further with water to $200 \mathrm{~mL}$. The samples were incubated for $5 \mathrm{~min}$ at room temperature and stopped by the addition of $360 \mu \mathrm{l}$ of $6 \mathrm{M}$ $\mathrm{H}_{2} \mathrm{SO}_{4}$. The absorption was measured at $540 \mathrm{~nm}$. Moreover, in order to quantify the amount of hydrogen peroxide accumulated in diluted honey, a calibration curve of $30 \%(\mathrm{v} / \mathrm{v})$ $\mathrm{H}_{2} \mathrm{O}_{2}$ dissolved to the concentration of $0.005-0.1 \mathrm{mM}$ was used. The measurements were performed in triplicate for each sample. Results were expressed as mM of hydrogen peroxide in $30 \%(\mathrm{v} / \mathrm{v})$ honey solution.

2.4.7. Determination of Sugars. Sugars analysis was performed only to ten samples of PDO honey (thyme-pine blend) due to insufficient quantities of other samples. Minor modifications were applied in the method of analysis with LC-RI of the Harmonized Methods of the International Honey Commission [18]: $3 \mathrm{~g}$ of honey was diluted to $100.0 \mathrm{~mL}$ of $\mathrm{ACN}: \mathrm{H}_{2} \mathrm{O}(1: 1 \mathrm{v} / \mathrm{v})$. After filtration, $20 \mu \mathrm{L}$ aliquots were injected into the HPLC chromatograph with column Lichrospher $100-\mathrm{NH} 2,250 \times 4 \mathrm{~mm}$ i.d., $5 \mu \mathrm{m}$, precolumn Lichrospher $100-\mathrm{NH} 2,5 \mu \mathrm{m}$, and refractive index detector. Isocratic elution was achieved by using $\mathrm{ACN}: \mathrm{H}_{2} \mathrm{O}$ $80-20(\mathrm{v} / \mathrm{v})$ at $1.3 \mathrm{~mL} / \mathrm{min}$ flow rate. Standard solution of sugars was prepared by dissolving $1.60 \mathrm{~g}$ of fructose, $1.50 \mathrm{~g}$ of glucose, and $0.3 \mathrm{~g}$ of sucrose in $100.0 \mathrm{~mL} \mathrm{ACN}: \mathrm{H}_{2} \mathrm{O}(1: 1 \mathrm{v} /$ v).

2.5. Statistical Analysis. Statistical data analysis was performed using the IBM SPSS software. One-way analysis of variance (ANOVA) was carried out to test the effect of one or several independent variables that defined groups of cases (botanical groups of honey samples) on the mean values of dependent variables. When a factor proved to cause significant differences $(P<0.05)$ in the mean of a dependent variable, Duncan's multiple range test (post hoc test) was applied in order to detect between which groups of cases differences occurred. The interactions between different dependent variables on the mean value of the dependent ones were investigated as well.

Multivariate statistical analysis was applied using the canonical discriminant analysis and Pearson's correlation analysis (proximity matrix produced for similarities between variables). 
TABLE 1: Results for color (Pfund grades), moisture content (W), electrical conductivity (EC), diastase activity (DN), hydroxymethylfurfural (HMF), and hydrogen peroxide (mM in $30 \% \mathrm{v} / \mathrm{v}$ aqueous honey solution) from honeys of different botanical origins.

\begin{tabular}{|c|c|c|c|c|c|c|}
\hline Sample code & Pfund grades $(\mathrm{mm})$ & $W(\mathrm{~g} / 100 \mathrm{~g})$ & $\mathrm{EC}(\mathrm{mS} / \mathrm{cm})$ & DN (Schade units) & HMF (mg/kg) & $\begin{array}{c}\text { Hydrogen peroxide } \\
(\mathrm{mM})(\text { mean } \pm \mathrm{SD}, n=3)\end{array}$ \\
\hline \multicolumn{7}{|l|}{ Thyme honey } \\
\hline $\mathrm{T} 1$ & 71 & 14.6 & 0.52 & 9.0 & 13.9 & $0.033 \pm 0.004$ \\
\hline $\mathrm{T} 2$ & 43 & 14.6 & 0.33 & 23.2 & 4.3 & $0.075 \pm 0.013$ \\
\hline T3 & 33 & 14.6 & 0.27 & 26.1 & 5.8 & $0.092 \pm 0.003$ \\
\hline $\mathrm{T} 4$ & 53 & 15.4 & 0.39 & 31.9 & 2.4 & $0.028 \pm 0.007$ \\
\hline T5 & 56 & 15.6 & 0.47 & 43.6 & 4.9 & $0.077 \pm 0.002$ \\
\hline T6 & 68 & 15.4 & 0.50 & 27.8 & 8.3 & $0.028 \pm 0.005$ \\
\hline T7 & 74 & 14.2 & 0.52 & 21.1 & 9.0 & $0.032 \pm 0.007$ \\
\hline T8 & 84 & 16.0 & 0.63 & 25.4 & 8.1 & $0.028 \pm 0.005$ \\
\hline T9 & 84 & 14.5 & 0.59 & 27.1 & 12.6 & $0.032 \pm 0.003$ \\
\hline $\mathrm{T} 10$ & 56 & 14.3 & 0.51 & 16.5 & 11.1 & $0.035 \pm 0.005$ \\
\hline T11 & 47 & 14.3 & 0.43 & 8.5 & 3.7 & $0.034 \pm 0.005$ \\
\hline $\mathrm{T} 12$ & 68 & 14.8 & 0.54 & 10.9 & 4.6 & $0.043 \pm 0.004$ \\
\hline \multicolumn{7}{|c|}{ PDO "Pefkothymaromelo Kritis" (blend thyme-pine) honey } \\
\hline PDO-1 & 76 & 14.4 & 0.74 & 9.2 & 4.5 & $0.041 \pm 0.006$ \\
\hline PDO-2 & 70 & 14.5 & 0.69 & 9.7 & 3.0 & $0.035 \pm 0.005$ \\
\hline PDO-3 & 74 & 14.7 & 0.65 & 9.5 & 11.5 & $0.034 \pm 0.006$ \\
\hline PDO-4 & 87 & 13.4 & 0.89 & 8.5 & 9.9 & $0.036 \pm 0.006$ \\
\hline PDO-5 & 80 & 14.0 & 0.95 & 13.3 & 4.5 & $0.048 \pm 0.006$ \\
\hline PDO-6 & 73 & 14.3 & 0.65 & 17.8 & 6.6 & $0.049 \pm 0.009$ \\
\hline PDO-7 & 72 & 14.6 & 0.66 & 7.3 & 2.8 & $0.031 \pm 0.006$ \\
\hline PDO-8 & 75 & 15.8 & 0.80 & 14.2 & 4.9 & $0.027 \pm 0.005$ \\
\hline PDO-9 & 76 & 14.7 & 0.68 & 18.0 & 11.0 & $0.038 \pm 0.006$ \\
\hline PDO-10 & 80 & 14.4 & 0.81 & 8.5 & 4.2 & $0.039 \pm 0.006$ \\
\hline PDO-11 & 90 & 14.4 & 0.93 & 7.7 & 4.6 & $0.043 \pm 0.006$ \\
\hline PDO-12 & 83 & 13.8 & 0.87 & 7.3 & 5.4 & $0.042 \pm 0.009$ \\
\hline \multicolumn{7}{|c|}{ Pine honeydew honey } \\
\hline P-1 & 80 & 14.5 & 1.16 & 5.2 & 1.2 & $0.030 \pm 0.005$ \\
\hline P-2 & 81 & 13.8 & 0.96 & 8.2 & 5.2 & $0.028 \pm 0.006$ \\
\hline $\mathrm{P}-3$ & 95 & 15.2 & 1.11 & 22.7 & 1.9 & $0.050 \pm 0.007$ \\
\hline \multicolumn{7}{|c|}{ Orange blossom (Citrus) honey } \\
\hline $\mathrm{C}-1$ & 35 & 16 & 0.19 & 15 & 36.9 & $0.010 \pm 0.002$ \\
\hline $\mathrm{C}-2$ & 31 & 15.2 & 0.20 & 11.4 & 7.8 & $0.054 \pm 0.009$ \\
\hline $\mathrm{C}-3$ & 26 & 16.4 & 0.45 & 22.8 & 12.8 & $0.050 \pm 0.004$ \\
\hline
\end{tabular}

\section{Results and Discussion}

3.1. Determination of Physicochemical Parameters. The physicochemical parameters (botanical origin, color, water content, electrical conductivity, diastase activity, and hydroxymethylfurfural) of all samples of honey examined are shown in Table 1, and results (mean value, standard deviation, median, minimum, and maximum values) are summarized in Table 2. From the results, it is obvious that all samples examined are within the permitted limits for honey and safe in terms of authenticity [21, 22].

As expected according to the literature, pine and PDO thyme-pine honeys show darker colors (average value: $85.3 \pm 8.4 \mathrm{~mm}$ and $78 \pm 6.1 \mathrm{~mm}$ Pfund grades, Table 2, respectively), while Citrus honeys had the lowest Pfund grades (average value: $30.7 \pm 4.5 \mathrm{~mm}$ ). Citrus honeys showed higher color values from other Citrus honeys reported in the literature by Persano Oddo et al. [23] (15.0 $\pm 6.6 \mathrm{~mm}$ Pfund), Castiglioni et al. [24] (11 $\pm 5 \mathrm{~mm}$ Pfund), and Sant'Ana et al. [25] (20.06 mm Pfund).
The Pfund values for thyme honey $(61.4 \pm 16.0 \mathrm{~mm}$ Pfund, Table 2) are close to the ones reported for average European thyme honey $(53.1 \pm 10.8 \mathrm{~mm})$ [13] and thyme honeys from Spain $(80 \pm 1.7 \mathrm{~mm})$ [26] and from New Zealand (range 47-84 $\mathrm{mm}$ Pfund) [26].

Moreover, according to a study focused on Greek honey samples [27], it was reported that Greek thyme honey samples showed Pfund grades within the range $35-85 \mathrm{~mm}$ which complies with our results. Higher Pfund values indicate higher content in phenolic compounds and flavonoids [28].

3.2. Determination of Sugars. Results for the determination of fructose, glucose, and sucrose in PDO thyme-pine honeys are shown in Table 3. According to El Sohaimy et al. [29], the sugar composition of honey is affected by the type of flowers used by the bees, as well as climate conditions. All samples contained sucrose below 3\% and total fructose + glucose higher than $50 \%$, exactly as in the description of this PDO product [21]. 
TABle 2: Variation of color (Pfund grades), moisture content ( $W$ ), electrical conductivity (EC), diastase activity (DN), hydroxymethylfurfural (HMF), and hydrogen peroxide ( $\mathrm{mM}$ in $30 \% \mathrm{v} / \mathrm{v}$ aqueous honey solution) among all honeys examined.

\begin{tabular}{|c|c|c|c|c|c|}
\hline & Mean & $\pm \mathrm{SD}(n)$ & Median & Min & Max \\
\hline \multicolumn{6}{|l|}{ Thyme honey $(n=12)$} \\
\hline Pfund grades $(\mathrm{mm})$ & 61.4 & 16.0 & 62.0 & 33.0 & 84.0 \\
\hline$W(\mathrm{~g} / 100 \mathrm{~g})$ & 14.9 & 0.59 & 14.6 & 14.2 & 16.0 \\
\hline $\mathrm{EC}(\mathrm{mS} / \mathrm{cm})$ & 0.48 & 0.10 & 0.50 & 0.27 & 0.63 \\
\hline $\mathrm{DN}$ & 22.6 & 10.2 & 24.3 & 8.5 & 43.6 \\
\hline HMF (mg/kg) & 7.4 & 3.7 & 7.0 & 2.4 & 13.9 \\
\hline $\mathrm{H}_{2} \mathrm{O}_{2}(\mathrm{mM})$ & 0.045 & 0.022 & 0.034 & 0.028 & 0.092 \\
\hline \multicolumn{6}{|c|}{ PDO "Pefkothymaromelo Kritis" (blend thyme-pine) honey $(n=12)$} \\
\hline Pfund grades $(\mathrm{mm})$ & 78.0 & 6.1 & 76.0 & 70.0 & 90.0 \\
\hline$W(\mathrm{~g} / 100 \mathrm{~g})$ & 14.4 & 0.6 & 14.4 & 13.4 & 15.8 \\
\hline $\mathrm{EC}(\mathrm{mS} / \mathrm{cm})$ & 0.77 & 0.10 & 0.77 & 0.65 & 0.91 \\
\hline $\mathrm{DN}$ & 10.9 & 3.9 & 9.4 & 7.3 & 18.0 \\
\hline $\mathrm{HMF}(\mathrm{mg} / \mathrm{Kg})$ & 6.1 & 3.0 & 4.8 & 2.8 & 11.5 \\
\hline $\mathrm{H}_{2} \mathrm{O}_{2}(\mathrm{mM})$ & 0.038 & 0.006 & 0.038 & 0.027 & 0.049 \\
\hline \multicolumn{6}{|c|}{ Pine honeydew honey $(n=3)$} \\
\hline Pfund grades $(\mathrm{mm})$ & 85.3 & 8.4 & 81.0 & 80.0 & 95.0 \\
\hline$W(\mathrm{~g} / 100 \mathrm{~g})$ & 14.5 & 0.7 & 14.5 & 13.8 & 15.2 \\
\hline $\mathrm{EC}(\mathrm{mS} / \mathrm{cm})$ & 1.08 & 0.10 & 1.11 & 0.96 & 1.16 \\
\hline $\mathrm{DN}$ & 12.1 & 9.4 & 8.2 & 5.1 & 22.7 \\
\hline HMF (mg/kg) & 2.8 & 2.1 & 1.9 & 1.2 & 5.2 \\
\hline $\mathrm{H}_{2} \mathrm{O}_{2}(\mathrm{mM})$ & 0.036 & 0.012 & 0.030 & 0.028 & 0.050 \\
\hline \multicolumn{6}{|c|}{ Orange blossom (Citrus) honey $(n=3)$} \\
\hline Pfund grades $(\mathrm{mm})$ & 30.7 & 4.5 & 31.0 & 26.0 & 35.0 \\
\hline$W(\mathrm{~g} / 100 \mathrm{~g})$ & 15.9 & 0.6 & 16.0 & 15.2 & 16.5 \\
\hline $\mathrm{EC}(\mathrm{mS} / \mathrm{cm})$ & 0.26 & 0.12 & 0.20 & 0.19 & 0.46 \\
\hline $\mathrm{DN}$ & 16.4 & 5.9 & 15.0 & 11.4 & 22.8 \\
\hline HMF (mg/kg) & 19.1 & 15.6 & 12.8 & 7.78 & 36.9 \\
\hline $\mathrm{H}_{2} \mathrm{O}_{2}(\mathrm{mM})$ & 0.038 & 0.024 & 0.050 & 0.010 & 0.054 \\
\hline
\end{tabular}

TABle 3: Results for the determination of fructose, glucose, and sucrose in PDO "Pefkothymaromelo Kritis" (blend thyme-pine honey) $(n=10)$.

\begin{tabular}{lccccc}
\hline Sample code & Fructose $(\mathrm{g} / 100 \mathrm{~g})$ & Glucose $(\mathrm{g} / 100 \mathrm{~g})$ & Fructose + glucose $(\mathrm{g} / 100 \mathrm{~g})$ & Sucrose $(\mathrm{g} / 100 \mathrm{~g})$ & Ratio [fructose]/[glucose] \\
\hline PDO-1 & 35.7 & 23.3 & 59.0 & n.d. & n.d. \\
PDO-2 & 34.8 & 22.9 & 57.8 & 0.7 & 1.5 \\
PDO-3 & 39.0 & 24.6 & 63.6 & 2.2 & 1.5 \\
PDO-4 & 33.4 & 20.7 & 54.1 & n.d. & 1.6 \\
PDO-5 & 35.0 & 20.8 & 55.8 & 2.4 & 1.6 \\
PDO-6 & 35.5 & 25.6 & 61.1 & 1.3 & 1.7 \\
PDO-7 & 34.0 & 22.3 & 56.3 & n.d. & 1.4 \\
PDO-8 & 33.8 & 24.0 & 57.9 & n.d. & 1.5 \\
PDO-10 & 33.9 & 20.5 & 54.4 & n.d. & 1.4 \\
PDO-11 & 33.6 & 20.3 & 53.8 & & $0.7 \pm 1.0$ \\
Mean value & & & $57.4 \pm 3.2$ & & 1.7 \\
\pm SD $(n=10)$ & $34.9 \pm 1.7$ & $22.5 \pm 1.9$ & & & $1.6 \pm 0.1$ \\
\hline
\end{tabular}

n.d.: not detected.

The average ratio of fructose to glucose for the honey samples analyzed was found equal to $1.6 \pm 0.1(n=10)$. This ratio depends largely on the source of the nectar from which the honey was extracted and allows evaluation of the crystallized glucose solubility levels in water as compared to fructose $[20,30,31]$. The amount of sucrose provides information about the maturity of honey as well as improper manipulation. High levels of sucrose indicate possible adulteration of honey $[20,21,32]$.
3.3. Determination of Hydrogen Peroxide. Results for hydrogen peroxide in the honey samples examined are shown in Table 1, and results (mean value, standard deviation, median, minimum, and maximum values) are summarized in Table 2. Results are in accordance with other studies $[20,33,34]$. Among the four different botanical groups, the average hydrogen peroxide concentration is in the order thyme $>$ PDO-thyme-pine $=$ pine $\approx$ Citrus but no significant differences were observed. 


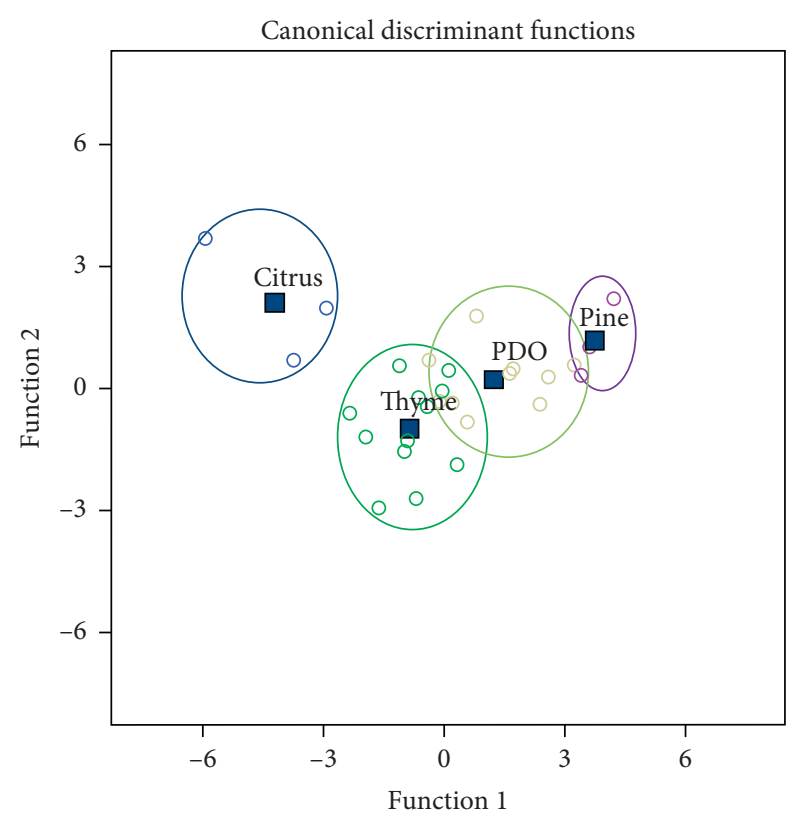

Botanical group

$\begin{array}{ll}\bigcirc \text { Citrus } & \bigcirc \text { Pine } \\ \text { Thyme } & \square \text { Group Centroid } \\ \text { PDO } & \end{array}$

Figure 1: Canonical discriminant analysis of all honey samples examined.

3.4. Statistical Evaluation of Results. The correlation coefficient of Pfund values and electrical conductivity were found equal to $0.94(n=12)$ for thyme, $0.91(n=12)$ for PDO thyme-pine honey, and $0.95(n=6)$ for pine and Citrus honeys. Thus, it is confirmed that electrical conductivity is strongly associated with honey color which is in accordance with other studies [35]. Furthermore, the correlation coefficients of the concentration of glucose with Pfund grades and electrical conductivity of PDO thyme-pine honey were found equal to -0.74 and $-0.79 \quad(n=10)$, respectively. Therefore, as the concentration of glucose increases, Pfund grades and electrical conductivity decrease with acceptable correlation.

All physicochemical parameters (except from sugars concentration) and concentration of hydrogen peroxide of all honey samples examined have been correlated by canonical discriminant analysis, which showed that $86.7 \%$ of the original grouped cases were correctly classified into the 4 botanical groups (Figure 1).

\section{Conclusions}

The present study showed that all honey samples from Crete produced hydrogen peroxide which plays an important role in the antibacterial activity of honey. Among the four different botanical groups, the average hydrogen peroxide concentration is in the order thyme $>$ PDO-thyme-pine$=$ pine $\approx$ Citrus, but no significant differences were observed. All physicochemical parameters (diastase activity, HMF content, moisture, electrical conductivity, color, and sugars) measured are in accordance with results of honeys from other countries [23-25].

Furthermore, univariate and multivariate statistics that have been applied to the analytical results have shown that a combination of the studied parameters can be also used to discriminate successfully honey sample groups of different botanical origins.

\section{Data Availability}

The data used to support the findings of this study are available from the corresponding author.

\section{Conflicts of Interest}

All authors declare no conflicts of interest.

\section{Authors' Contributions}

Panagiota Gotsiou was responsible for the conceptualization. Panagiota Gotsiou, Amalia Alygizou, Sofia Loupassaki, and Antony C. Calokerinos were responsible for the design of experiments and results. Amalia Alygizou and Spyros Grigorakis conducted statistical analyses. Amalia Alygizou, Sofia Loupassaki, and Antony C. Calokerinos were responsible for interpretation of results. All authors equally contributed to writing and editing the manuscript. All authors approved the submission of the final manuscript.

\section{Acknowledgments}

The authors wish to thank Dr. George Baourakis, Director of Mediterranean Agronomic Institute of Chania (M.A.I.Ch.)/ Centre International de Hautes Etudes Agronomiques Méditerranéennes, for giving permission to use all necessary facilities of the Department of Food Quality \& Chemistry of Natural Products.

\section{References}

[1] P. H. S. Kwakman and S. A. J. Zaat, "Antibacterial components of honey," IUBMB Life, vol. 64, no. 1, pp. 48-55, 2012.

[2] A. A. Mahmoud and A. A. Owayss, "A modified method to determine hydrogen peroxide activity as a criterion for bee honey quality," Annals of Agricultural Science Moshtohor Journal, vol. 44, no. 4, pp. 1629-1639, 2006.

[3] J. Irish, S. Blair, and D. A. Carter, "The antibacterial activity of honey derived from Australian flora," PLoS One, vol. 6, no. 3, Article ID e18229, 2011.

[4] J. H. Dustmann, "Antibacterial effect of honey," Apiacta, vol. 14, no. 1, pp. 7-11, 1979.

[5] R. J. Weston, K. R. Mitchell, and K. L. Allen, "Antibacterial phenolic components of New Zealand Manuka honey," Food Chemistry, vol. 64, no. 3, pp. 295-301, 1999.

[6] P. C. Molan, "Using honey in wound care," Research Commons, University of Waikato Research, vol. 3, no. 2b, pp. 21-24, 2006.

[7] M. Bucekova, I. Valachova, L. Kohutova, E. Prochazka, J. Klaudiny, and J. Majtan, "Honeybee glucose oxidase-its expression in honeybee workers and comparative analyses of its content and $\mathrm{H}_{2} \mathrm{O}_{2}$-mediated antibacterial activity in 
natural honeys," Naturwissenschaften, vol. 101, no. 8, pp. 661-670, 2014.

[8] C. Alaux, F. Ducloz, D. Crauser, and Y. Le Conte, "Diet effects on honeybee immunocompetence," Biology Letters, vol. 6, no. 4 , pp. $562-565,2010$.

[9] L. M. Bang, C. Buntting, and P. Molan, "The effect of dilution on the rate of hydrogen peroxide production in honey and its implications for wound healing," The Journal of Alternative and Complementary Medicine, vol. 9, no. 2, pp. 267-273, 2003.

[10] K. Brudzynski, "Effect of hydrogen peroxide on antibacterial activities of Canadian honeys," Canadian Journal of Microbiology, vol. 52, no. 12, pp. 1228-1237, 2006.

[11] K. Brudzynski, K. Abubaker, L. St-Martin, and A. Castle, "Reexamining the role of hydrogen peroxide in bacteriostatic and bactericidal activities of honey," Frontiers in Microbiology, vol. 2, no. 213, pp. 1-9, 2011.

[12] S. Li, X. Zhang, Y. Shan et al., "Qualitative and quantitative detection of honey adulterated with high-fructose corn syrup and maltose syrup by using near-infrared spectroscopy," Food Chemistry, vol. 218, pp. 231-236, 2017.

[13] Q. Chang, K. Deng, L. Zhu, G. Jiang, C. Yu, and H. Tang, "Determination of hydrogen peroxide with the aid of peroxidase-like $\mathrm{Fe}_{3} \mathrm{O}_{4}$ magnetic nanoparticles as the catalyst," Microchimica Acta, vol. 165, no. 3-4, pp. 299-305, 2009.

[14] N. Nasirizadeh, Z. Shekari, A. Nazari, and M. Tabatabaee, "Fabrication of a novel electrochemical sensor for determination of hydrogen peroxide in different fruit juice samples," Journal of Food and Drug Analysis, vol. 24, no. 1, pp. 72-82, 2016.

[15] P. Gimeno, C. Bousquet, N. Lassu et al., "High-performance liquid chromatography method for the determination of hydrogen peroxide present or released in teeth bleaching kits and hair cosmetic products," Journal of Pharmaceutical and Biomedical Analysis, vol. 107, pp. 386-393, 2015.

[16] H. Yue, X. Bu, M.-H. Huang, J. Young, and T. Raglione, "Quantitative determination of trace levels of hydrogen peroxide in crospovidone and a pharmaceutical product using high performance liquid chromatography with coulometric detection," International Journal of Pharmaceutics, vol. 375, no. 1-2, pp. 33-40, 2009.

[17] K. Karasawa, S. Haraya, S. Okubo, and H. Arakawa, "Novel assay of antibacterial components in manuka honey using lucigenin-chemiluminescence-HPLC," Analytica Chimica Acta, vol. 954, pp. 151-158, 2017.

[18] S. Bogdanov. Harmonized Methods of the International Honey Commission. International Honey Commission. International Honey Commission, 2009, http://www.ihc-platform.net/ihc methods2009.pdf.

[19] J. W. White and M. H. Subers, "Studies on honey inhibine. 2. A chemical assay," Journal of Apicultural Research, vol. 2, no. 2, pp. 93-100, 1963.

[20] P. H. S. Kwakman, A. A. te Velde, L. de Boer, C. M. J. E. Vandenbroucke-Grauls, and S. A. J. Zaat, "Two major medicinal honeys have different mechanisms of bactericidal activity," PLoS One, vol. 6, no. 3, pp. 3-9, 2011.

[21] Council directive 2001/110/EC of 20 december 2001, Relating to honey. Official Journal of the European Communities, L 10/ 12.01.2002: 47-52. https://eur-lex.europa.eu/LexUriServ/Lex UriServ.do?uri=OJ:L:2002:010:0047:0052:EN:PDF.

[22] EU Official Journal C 108, 06.04.2017. PDO Pefkothymaromelo Kritis' EU No: PDO-EL-02142. https://eur-lex.europa. eu/legal-content/EN/TXT/PDF/?uri=OJ:JOC_2017_108_R_ 0018\&from $=\mathrm{EN}$.
[23] L. Persano Oddo, L. Piana, S. Bogdanov et al., "Botanical species giving unifloral honey in Europe," Apidologie, vol. 35, no. 1, pp. S82-S93, 2004.

[24] S. Castiglioni, M. Stefano, P. Astolfi, and P. Carloni, "Chemometric approach to the analysis of antioxidant properties and colour of typical Italian monofloral honeys," International Journal of Food Science \& Technology, vol. 52, no. 5, pp. 1138-1146, 2017.

[25] L. D. O. Sant'Ana, A. B. Buarque Ferreira, M. C. A. Lorenzon, R. L. L. Berbara, and R. N. Castro, "Correlation of total phenolic and flavonoid contents of brazilian honeys with color and antioxidant capacity," International Journal of Food Properties, vol. 17, no. 1, pp. 65-76, 2014.

[26] I. Escriche, M. Juan-Borrás, J. Soto, L. Gil-Sánchez, and A. Pascual-Maté, "Antioxidant activity and physico-chemical parameters for the differentiation of honey using a potentiometric electronic tongue," Journal of the Science of Food and Agriculture, vol. 97, no. 7, pp. 2215-2222, 2017.

[27] J. M. Stephens, R. C. Schlothauer, B. D. Morris et al., "Phenolic compounds and methylglyoxal in some New Zealand manuka and kanuka honeys," Food Chemistry, vol. 120, no. 1, pp. 78-86, 2010.

[28] A. Tsigouri, M. Passaloglou-Katrali, and O. Sabatakou, "Palynological characteristics of different unifloral honeys from Greece," Grana, vol. 43, no. 2, pp. 122-128, 2004.

[29] S. A. El Sohaimy, S. H. D. Masry, and M. G. Shehata, "Physicochemical characteristics of honey from different origins," Annals of Agricultural Sciences, vol. 60, no. 2, pp. $279-287,2015$.

[30] F. Tornuk, S. Karaman, I. Ozturk et al., "Quality characterization of artisanal and retail Turkish blossom honeys: determination of physicochemical, microbiological, bioactive properties and aroma profile," Industrial Crops and Products, vol. 46, pp. 124131, 2013.

[31] O. Escuredo, M. Míguez, M. Fernández-González, and M. Carmen Seijo, "Nutritional value and antioxidant activity of honeys produced in a European Atlantic area," Food Chemistry, vol. 138, no. 2-3, pp. 851-856, 2013.

[32] E. de la Fuente, A. I. Ruiz-Matute, R. M. Valencia-Barrera, J. Sanz, and I. Martínez Castro, "Carbohydrate composition of Spanish unifloral honeys,” Food Chemistry, vol. 129, no. 4, pp. 1483-1489, 2011.

[33] C. Cimpoiu, A. Hosu, V. Miclaus, and A. Puscas, "Determination of the floral origin of some Romanian honeys on the basis of physical and biochemical properties," Spectrochimica Acta Part A: Molecular and Biomolecular Spectroscopy, vol. 100, pp. 149-154, 2013.

[34] P. Sowa, D. Grabek-Lejko, M. Wesołowska, S. Swacha, and M. Dżugan, "Hydrogen peroxide-dependent antibacterial action of Melilotus albus honey," Letters in Applied Microbiology, vol. 65, no. 1, pp. 82-89, 2017.

[35] I. Flanjak, D. Kenjerić, D. Bubalo, and L. Primorac, "Characterisation of selected Croatian honey types based on the combination of antioxidant capacity, quality parameters, and chemometrics," European Food Research and Technology, vol. 242, no. 4, pp. 467-475, 2016. 